
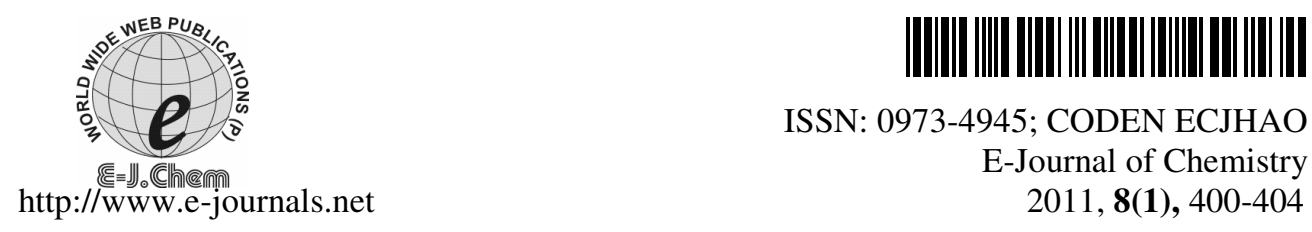

ISSN: 0973-4945; CODEN ECJHAO

E-Journal of Chemistry 2011, 8(1), 400-404

\title{
Characterization of Fly Ash Generated from Parichha Thermal Power Station in Jhansi, India
}

\author{
K. VIMLESH* ${ }^{*}$ and A. K. GIRI \\ Institute of Environment and Development Studies \\ Bundelkhand University, Jhansi, India \\ mahendra_mann1979@rediffmail.com
}

Received 14 July 2010; Accepted 26 August 2010

\begin{abstract}
Ash samples were collected from a dumping site (fly ash) and an electronic precipitator (ESP) of a 640MW thermal power station for characterization. Analysis of ash sample showed that the major matrix elements in fly ash were $\mathrm{Si}$ and $\mathrm{Al}$ together with significant percentage of $\mathrm{K}$, $\mathrm{Fe}, \mathrm{Ca}$, and $\mathrm{Mg}$. Some of the biologically toxic elements $\mathrm{Ni}, \mathrm{Cr}, \mathrm{Pb}, \mathrm{B}$, and Mo, were also present in substantial amounts. The saturation moisture percentages of both ashes were higher, but bulk density lower, than the normal cultivated soils.
\end{abstract}

Keywords: Fly ash, Thermal power station, Toxic elements.

\section{Introduction}

Increased use of coal for electric power generation results in large quantities of fly ash and other residues which require proper handling and disposal. In India, about $75 \%$ of the electricity is generated by coal based thermal power plants which produce nearly 65 million tons/ year of fly ash as a by product ${ }^{1}$. Disposal of fly ash has adverse impacts on terrestrial and aquatic ecosystems due to leaching of toxic substances from the ash into soil and ground water as well as reduction in plant establishment and growth. The fly ash is currently used in land filling in construction industry as filler in asphalt mix stabilizer for road bases thermal insulation and deodorization of animal wastes ${ }^{2}$. Fly ash is disposed of either by dry or wet methods. In dry disposal the fly ash is dumped in land fills and fly ash basins. In the wet method the fly ash is washed out with water in to the artificial lagoons and is called pond ash. Both methods ultimately lead to dumping the fly ash on open land, which degrades the soil and endangers human health and the environment. Physical and chemical properties of fly $\operatorname{ash}^{3}$ depend on the nature of parent coal, conditions of combustion, type of emission control devices and storage and handling methods. 


\section{Experimental}

Study area

The present study was conducted around the ash disposal sites of Parichha thermal power station. It is situated in Jhansi district of Uttar Pradesh, India. The Parichha thermal power station of Uttar Pradesh is situated at a height of about 240 meter above mean sea level (amsl). The power station is owned by central government, is a coal fired station located on National highway No 25 on the northern bank of Betwa river in Jhansi district. Normal slope of the region is observed from southwest to northwest to north east direction. Jhansi district is situated $24^{0} 11^{\prime} \mathrm{N}$ to $25^{\circ} 57^{\prime} \mathrm{N}$ latitude and $78^{0} 10^{\prime} \mathrm{E}$ to $79^{\circ} 23^{\prime} \mathrm{E}$ longitude in the semi arid region of the country.

\section{Sampling}

Samples of coal combustion waste products, namely fly ash, were collected for the study. The fly ash samples were collected in the following manner: the waste disposal site divided into 50 by $100 \mathrm{~m}$ grids, then about $0.5 \mathrm{~kg}$ samples was taken at the corner and in the middle of the grid at a depth of $-20 \mathrm{~cm}$, all of the samples thoroughly mixed to obtain about $2.5 \mathrm{~kg}$ representative sample for the given grid

\section{Laboratory methods}

Composite fly ash samples were collected in the month of June 2007 and were analyzed for different parameters. Atomic absorption spectrophotometer techniques were used for the analyses of major components such as $\mathrm{SiO}_{2}, \mathrm{SO}_{3}, \mathrm{Al}_{2} \mathrm{O}_{3}, \mathrm{Fe}_{2} \mathrm{O}_{3}, \mathrm{MgO}, \mathrm{CaO}, \mathrm{Na}_{2} \mathrm{O}, \mathrm{K}_{2} \mathrm{O}$ and $\mathrm{TiO}_{2}$. The equipment was calibrated at the beginning and end of each testing session by injecting various volumes of the standard solution by the analyst. The physico chemical parameters were analyzed as per the standards methods ${ }^{4}$. The $\mathrm{pH}$ and EC of the fly ash were extracting measured in 1:5 extract ${ }^{4}$. Physical properties of the fly ash such as bulk density, maximum water holding capacity were analyzed as per the methods of soil analysis Nutrient parameters such as nitrogen, phosphorus and potash were analyzed as per the standard procedures of Black and Jackson ${ }^{4,5}$. The DTPA extractable cation, $\mathrm{Fe}, \mathrm{Mn}, \mathrm{Zn}, \mathrm{Cu}, \mathrm{Pb}, \mathrm{Ni}$, As and $\mathrm{Cr}$ were determined by the method outlined by Lindsay and Norwell ${ }^{6}$. Organic carbon was estimated as per the Walkley and Black $^{7}$ method. Heavy metals like $\mathrm{Cr}, \mathrm{Zn}, \mathrm{Mn}$, $\mathrm{Pb}, \mathrm{Ni}$ and $\mathrm{Cd}$ were analyzed in fly ash samples using Atomic Absorption Spectrophotometer. 0.5 gram of fly ash sample was dissolved in $20 \mathrm{~mL}$ of $(1: 4)$ nitric:perchloric acid. The samples were allowed to digest till the white colored solution is formed. Then distilled water was added to the samples and was allowed to cool. All chemicals used in the study were obtained from Merck, India/ Germany and were of analytical grade. Deionized water was used throughout the study. All the glasswares and other containers were thoroughly cleaned and rinsed with deionized water several times prior to use. These filtered samples were directly used for analysis on AAS model Perkin Elmer 3500 at the Wild life Institute of Dehradun, India. International soil reference materials were used to prepare calibration curves for different trace metals and to check the accuracy of the analytical data. The limits of detection for various elements were as follows: $0.05 \mathrm{mg} \mathrm{Fe} \mathrm{L}^{-1}, 0.02 \mathrm{mg} \mathrm{Mn} \mathrm{L}{ }^{-1}$, $0.008 \mathrm{mg} \mathrm{Zn} \mathrm{L}^{-1}, 0.025 \mathrm{mg} \mathrm{Cu} \mathrm{L}^{-1}, 0.04 \mathrm{mg} \mathrm{Ni} \mathrm{L}^{-1}, 0.06 \mathrm{mg} \mathrm{Pb} \mathrm{L}^{-1}$ and $0.05 \mathrm{mg} \mathrm{Co} \mathrm{L}^{-1}$. The detection limits for all the trace elements were better than $1 \mathrm{mg} / \mathrm{mL}$.

\section{Results and Discussion}

\section{Chemical composition of fly ash}

The chemical composition of fly ash is shown in Table 1 which has alkaline $\left(\mathrm{Na}_{2} \mathrm{O}+\mathrm{K}_{2} \mathrm{O}\right)$ in the range of 1.5 to 2.0 wet percent and alkaline rare earth's $(\mathrm{CaO}+\mathrm{MgO})$ less than 3.0 
wet percent. The major constituents are $\mathrm{SiO}_{2} 58$ to 60 wet percent and alumina 27 to 28 wet percent. $\mathrm{Fe}_{2} \mathrm{O}_{3}$ does not exceed 5.5 wet percent. In addition to the above fly ash samples have micro nutrients such as $\mathrm{Cu}, \mathrm{Fe}, \mathrm{Zn}, \mathrm{Mn}$ and macro nutrients like available nitrogen, phosphorus, potassium, sodium and Sulphur.

\section{General characteristics of fly ash}

The selective physical and chemical properties of the fly ash of Parichha Thermal Power Station (PTPS) are shown in Table 2. The $\mathrm{pH}$ of $\mathrm{H}_{2} \mathrm{O}$ ranged between 5.45 and 6.52 with an average of 6.11 respectively. In India, fly ash is generally highly alkaline due to low sulfur content of coal and presence of hydroxides and carbonates of calcium and magnesium ${ }^{8}$. The soluble salt content of fly ash is measured by an assessment of electrical conductivity (EC) of water extract. The average $\mathrm{ECH}_{2} \mathrm{O}(1: 1)$ and $\mathrm{ECH}_{2} \mathrm{O}(1: 2.5)$ were found as 0.33 and 0.23 $\mathrm{dS} / \mathrm{m}$, respectively. The level of organic carbon in fly ash was found to be less than $1 \%$ and bulk density was found less than $1 \mathrm{~g} / \mathrm{cc}$. It can be seen that this was texturally fly ash (sand, $65.7 \%$; silt, $52 \%$, clay $15.0 \%$ ) and ESP ash (sand, $40.8 \%$; silt, $19.3 \%$, clay 9.8\%). The water holding capacity of fly ash and ESP ash were $60 \%$ and $58.8 \%$. As a result of higher temperature of coal combustion $\left(1500{ }^{\circ} \mathrm{C}\right)$ fly ash possesses some unique characteristics. It occurs primarily as micron and submicron spherical particles with smaller particles entrapped with in large spheres ${ }^{9}$. The term cenospheres (hollow spheres) has been used to describe these particles which are a common phenomenon in fly ashes. The external and internal surfaces of these particles may contribute to an increase of surface area and porosity. Thus the porosity associated with surfaces of fly ash particles contribute to increased saturation percentage of both the ashes. The portion of finer particles in the ESP ash was greater than fly ash (Table 2), therefore, the saturation percentage of ESP ash was higher than fly ash due to the low bulk density and thus higher porosity fly ash might be used to increase the water retentions capacity of coarse textured soils ${ }^{10}$ observed that the addition of $10 \%$ by weight of ash increased the available water holding capacity by factors of 7.2 and $13.5 \%$ for the fine and coarse sands, respectively. However, the associated disadvantage of low bulk density is the potential for increased dust formation creating problems for transformation and storage.

Table 1. Major elemental concentration of the collected fly ash and ESP ash samples from thermal power plant

\begin{tabular}{lll}
\hline Elements & $\begin{array}{c}\text { Fly ash } \\
\text { ppm }\end{array}$ & $\begin{array}{l}\text { ESP ash } \\
\text { ppm }\end{array}$ \\
\hline $\mathrm{SiO}_{2}$ & 61.5 & 56.65 \\
$\mathrm{TiO}_{2}$ & 1.01 & 0.98 \\
$\mathrm{Al}_{2} \mathrm{O}_{3}$ & 31.2 & 21.65 \\
$\mathrm{Fe}_{2} \mathrm{O}_{3}$ & 3.6 & 2.6 \\
$\mathrm{CaO}$ & 1.0 & 1.6 \\
$\mathrm{MgO}$ & 1.40 & 1.7 \\
$\mathrm{P}_{2} \mathrm{O}_{5}$ & 0.02 & 0.01 \\
$\mathrm{~K}_{2} \mathrm{O}$ & 1.64 & 0.96 \\
$\mathrm{Na}_{2} \mathrm{O}$ & 0.98 & 1.45 \\
$\mathrm{SO}_{3}$ & 3.29 & 2.24 \\
\hline
\end{tabular}

Table 2. Some physical and chemical characteristics of fly ash and ESP ash

\begin{tabular}{lll}
\hline Characteristics & Fly ash & ESP ash \\
\hline Organic carbon, \% & 0.78 & 0.39 \\
Bulk density, g/cc & 0.88 & 0.77 \\
$\begin{array}{l}\text { Saturation moisture } \\
\text { percentage }\end{array}$ & 58.48 & 56.82 \\
pH & & \\
EC & 6.6 & 5.8 \\
Sand, \% & 0.14 & 0.11 \\
Silt, \% & 65.7 & 40.8 \\
Clay, \% & 52 & 19.3 \\
Texture & 15.3 & 9.8 \\
Water holding & Silt loam & Clay \\
Capacity, \% & 60 & 58.8 \\
\hline
\end{tabular}




\section{Heavy metals in fly ash}

The EDTA-extractable heavy metals in fly ash were found higher than DTPA-extractable metals, which were in the following order: $\mathrm{Mn}\left(6.7 \mathrm{mg} \mathrm{kg}^{-1}\right)>\mathrm{Cu}\left(2.8 \mathrm{mg} \mathrm{kg}^{-1}\right)>\mathrm{Zn}$ $\left(2.2 \mathrm{mg} \mathrm{kg}^{-1}\right)>\mathrm{Pb}\left(1.64 \mathrm{mg} \mathrm{kg}^{-1}\right)>\mathrm{Ni}\left(1.1 \mathrm{mg} \mathrm{kg}^{-1}\right)>\mathrm{Cr}=$ Co below the detection limit (bdl). The EDTA extractable metal constituted $11.5 \%$ of total $\mathrm{Cu}, 9.7 \%$ of total $\mathrm{Pb}, 5.3 \%$ of $\mathrm{Ni}, 4.8 \%$ of total $\mathrm{Zn}$ and $2 \%$ of total $\mathrm{Mn}$. When considering the total metal concentrations in fly ash, $\mathrm{Mn}\left(318 \mathrm{mg} \mathrm{kg}^{-1}\right)$ was the most abundant metal followed by $\mathrm{Zn}\left(44.2 \mathrm{mg} \mathrm{kg}^{-1}\right)>\mathrm{Cu}$ $\left(24.3 \mathrm{mg} \mathrm{kg}^{-1}\right)>\mathrm{Ni}\left(21 \mathrm{mg} \mathrm{kg}^{-1}\right)>\mathrm{Pb}\left(16.8 \mathrm{mg} \mathrm{kg}^{-1}\right)$. Co and $\mathrm{Cr}$ were below the detection limit, while concentration of Fe was not analyzed (Table 3). Following observations could be made by comparing fresh fly ash with ESP ash. Total $\mathrm{Cu}$ was found more $(34.75 \mathrm{mg} / \mathrm{kg})$ in fly ash, however, DTPA-Cu was found about twice $(1.4 \mathrm{mg} / \mathrm{kg})$ the concentration in fly ash. The reasons could be the lack of organic matter in fly ash. In contrast, concentration of total $\mathrm{Zn}$ was found fresh fly ash is $44 \mathrm{mg} / \mathrm{kg}$ and ESP ash $27 \mathrm{mg} / \mathrm{kg}$. The lesser concentration of $\mathrm{Zn}$ in ESP ash may be due to fly ash. Fe and $\mathrm{Zn}$ were concentration of fly ash and ESP ash $1.54 \mathrm{mg} / \mathrm{kg}$ and $0.17 \mathrm{mg} / \mathrm{kg}$, respectively ${ }^{11}$. Out of 7 metals studied, concentration of total and EDTA-Mn $(6.7 \mathrm{mg} / \mathrm{kg})$ was found highest in the samples. Total Mn concentration in fresh fly ash $(328 \mathrm{mg} / \mathrm{kg})$ was similar to ESP ash; the concentration was found $131 \mathrm{mg} / \mathrm{kg}$. The probable reasons could be the alkaline nature of fresh fly ash. This was further confirmed by DTPA-Mn concentration of $4.2 \mathrm{mg} / \mathrm{kg}$ found in ESP ash having $\mathrm{pH}$ of 6.1 . Total $\mathrm{Pb}$ concentration in fresh fly ash is $17 \mathrm{mg} / \mathrm{kg}$. Total concentration of $\mathrm{Ni}$ was found higher in fly ash ${ }^{12,13}$. However, DTPA-Ni in fresh fly ash was found lower $(0.31 \mathrm{mg} / \mathrm{kg})$ compared to ESP ash $(0.82 \mathrm{mg} / \mathrm{kg})$. The lower value of DTPA-Ni in fresh fly ash due to its alkaline nature.

Table 3. Heavy metal concentration in fly ash and ESP ash

\begin{tabular}{lll}
\hline Heavy metal & Fly ash, ppm & ESP ash, ppm \\
\hline $\mathrm{Cu}$ (Total) & 24.3 & 15.8 \\
$\mathrm{Cu}$ (EDTA) & 2.8 & $\mathrm{NA}$ \\
$\mathrm{Cu}$ (DTPA) & 1.4 & 1.14 \\
$\mathrm{Zn}$ (Total) & 44.2 & 26.67 \\
$\mathrm{Zn}$ (EDTA) & 2.2 & $\mathrm{NA}$ \\
$\mathrm{Zn}$ (DTPA) & 0.95 & 2.35 \\
$\mathrm{Mn}$ (Total) & 328.4 & 135.8 \\
$\mathrm{Mn}$ (EDTA) & 6.8 & $\mathrm{NA}$ \\
$\mathrm{Mn}$ (DTPA) & 1.4 & 4.14 \\
$\mathrm{~Pb}$ (Total) & 32.46 & 8.33 \\
$\mathrm{~Pb}$ (EDTA) & 3.2 & $\mathrm{NA}$ \\
$\mathrm{Pb}$ (DTPA) & 1.46 & 0.96 \\
$\mathrm{Ni}$ (Total) & 43.42 & 23.1 \\
$\mathrm{Ni}$ (EDTA) & 1.78 & $\mathrm{NA}$ \\
$\mathrm{Ni}$ (DTPA) & 0.42 & 0.55 \\
\hline \multicolumn{3}{c}{ NA: Not Applicable }
\end{tabular}

\section{Conclusion}

Increasing demand for coal based energy will bound to produce more fly ash. The major concerns associated with coal burnt fly ash are enhanced rate of production, its underutilization and fly ash mound management for storage. Fly ash incorporation in agricultural field by its carriage from fly ash mounds/chimneys due to wind and rainfall actions modifies 
the soil and crop canopy environments, thereby influencing the crop yield. Hence, coal fired power station must strive further to upgraded with all advanced technology to reduce generation of fly ash. An alternative recycle option for fly would be a best solution for controlling storage related problems at the production side.

\section{Acknowledgements}

Authors would like to thank University Grant Commission (UGC), Govt. of India, and New Delhi for providing financial support in the form of JRF and SRF to carrying out this research work

\section{References}

1. Sahu K C, Indian J Environ Protect., 1998, 18, 498-504.

2. Asha A Juwarkar and Hemlata P Jambhulker, Environ Monit Assess., 2008, 139, 355-365.

3. Schutter M E and Fuhrman J, J Environ Qual., 1999, 28, 648-652.

4. Black C A, Methods for Soil Analysis, (American Society of Agronomy, Madison, WI, 1965), Part 2, 1562-1565.

5. Jackson M L, Soil chemical analysis. Prentice-Hall India Pvt. Ltd, Delhi, India, 1967.

6. Lindsay WL and Norvell W A, Soil Sci Soc Am., 1978, 42, 421-428.

7. Walkley A and Black CA, Soil. Sci 1934, 37, 29-38.

8. Maiti S K and Nandhini S, NHEEI, Bangalore, November 17-19, 2004.

9. Mittra B N, Karmakar S, Swain D K and Ghosh BC, Fuel, 2005, 84, 1447-1451.

10. Tripathi R D, Vajpayee P, Singh N, Rai U N, Kumar A and Ali M B, Chemosphere, 2004, 54, 1581-1588.

11. Carlson C C and Adriano D C, J Environ Qual 1993, 22, 227-247.

12. Pathan S M,Aylmore L A G and Colmer T D, J Environ Qual., 2003, 32, 687-693.

13. Misra L C and Shukla K L, Environ Pollut., (Series A), 1986, 42, 1-3. 


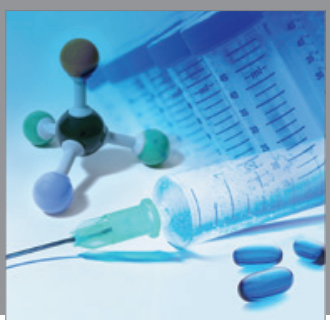

International Journal of

Medicinal Chemistry

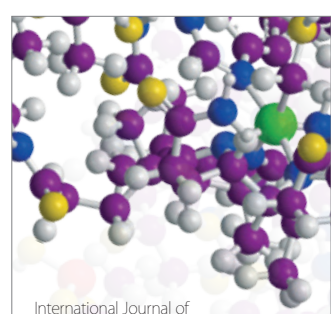

Carbohydrate Chemistry

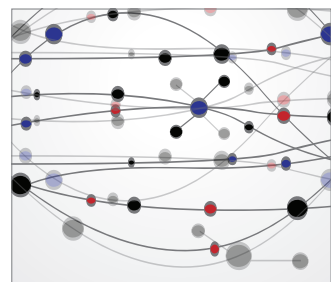

The Scientific World Journal
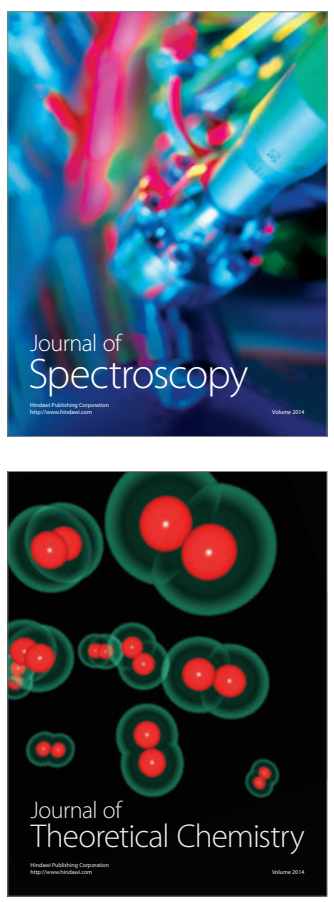
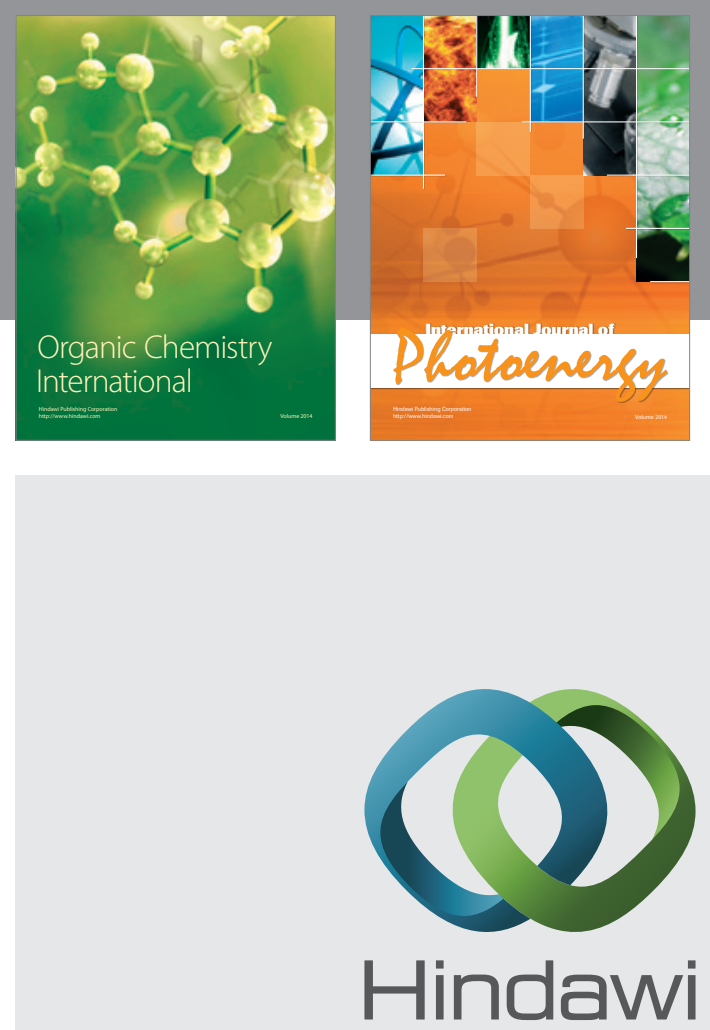

Submit your manuscripts at

http://www.hindawi.com
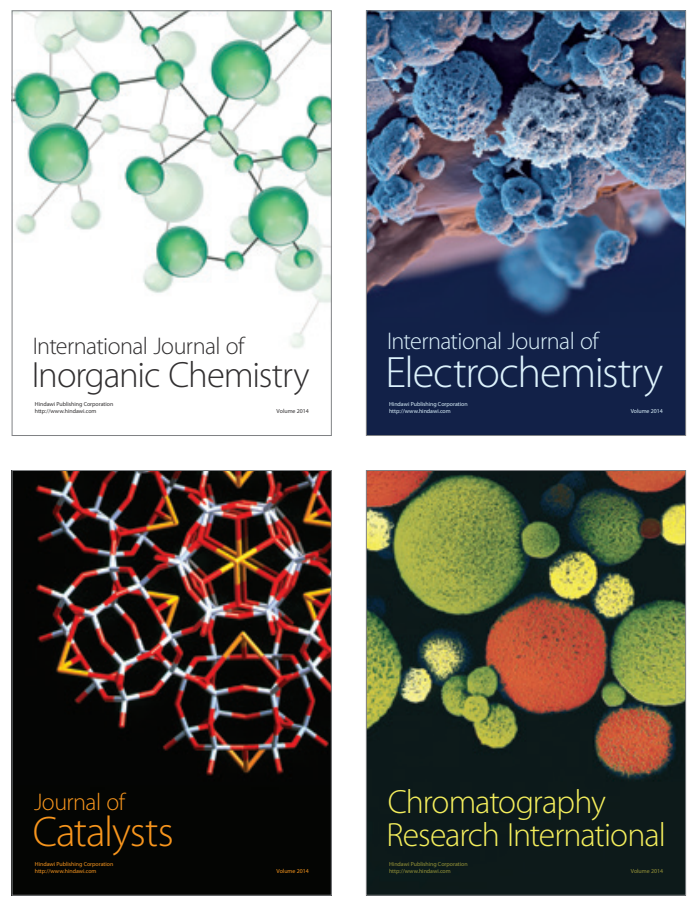
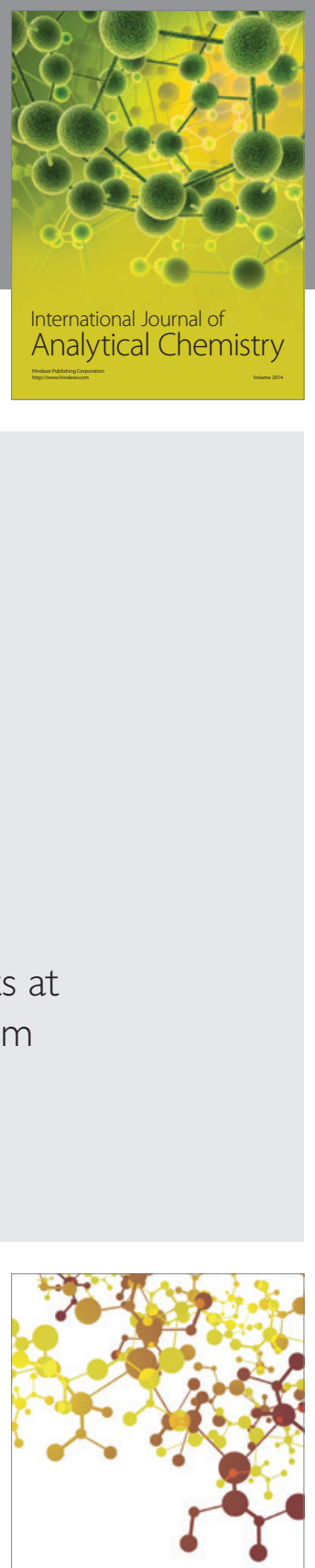

Journal of

Applied Chemistry
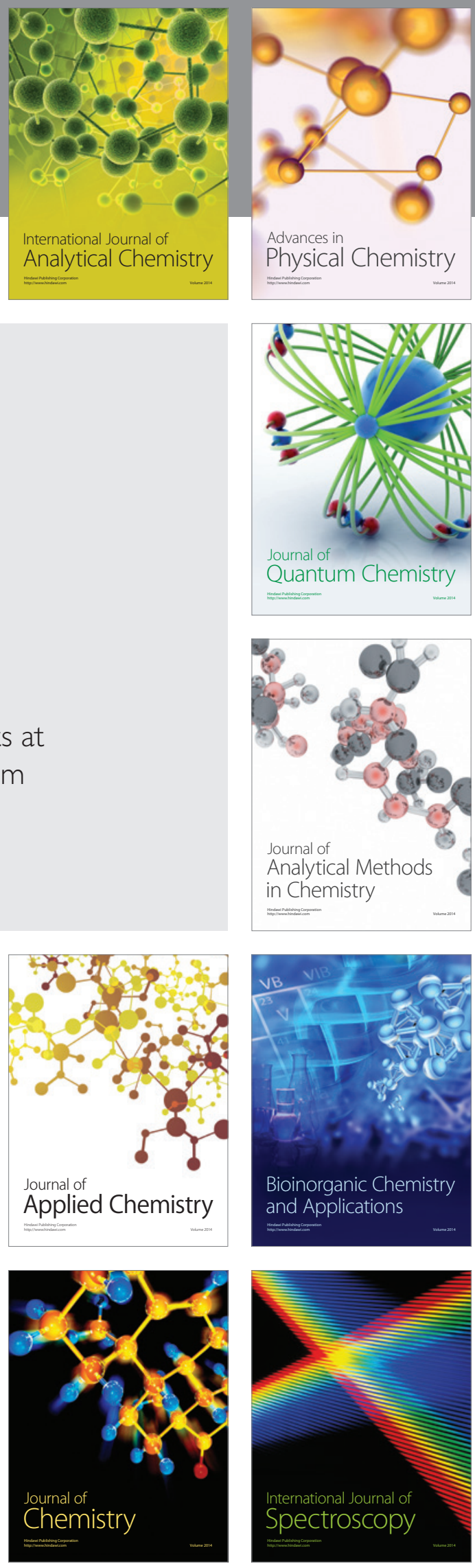